\title{
Cuajilote (Parmentiera aculeata (Kunth) Seem.): A Potential Fruit for Ruminant Feed
}

\author{
Pérez-Morales, S. ${ }^{1}$; Crosby-Galván, M.M. ${ }^{2 *}$; Ramírez-Mella, M. ${ }^{2}$; Bárcena-Gama, J.R. ${ }^{2}$; \\ Hernández-Mendo, O. $^{2}$; Grosby-Galván E.M. ${ }^{2}$ \\ 1 Colegio de Postgraduados Campus Montecillo, Programa de Ganadería, Carretera México-Texcoco km \\ 36.5, Montecillo, Texcoco, Estado de México. \\ 2 CONACyT-Colegio de Postgraduados Campus Campeche, Carretera Haltunchén-Edzná km 17.5, \\ Sihochac, Champotón, Campeche, México. \\ * Correspondence: maria@colpos.mx, seleneperez1008@outlook.com
}

\begin{abstract}
Objective: to review previous researches about the use of the fruits of the cuajilote tree (Parmentiera aculeata) as ovine feed.

Design/Methodology/Approach: this research was conducted, using all the available sources: science articles, conference reports, and books.

Results: P. aculeata (cuajilote) is generally used to provide shade, and as live fence, wood or firewood. However, it can also be used as forage. Both the foliage and the fruit have excellent nutritional qualities; additionally, the fruits are available during the dry season and free grazing cattle avidly eat them. Nevertheless, the nutritional value and the ruminal availability of this fruit's dry matter — during various ripeness stages - are unknown; it is also said to have medicinal properties.

Study Limitations and Implications: the cuajilote fruit was used in in vitro tests to remove protozoa from the ruminal fluid of bovines (defanuation); therefore, there are few in vitro researches about the use of cuajilote in a wholemeal diet as animal feed and about its maximum inclusion tolerance in ruminants.

Findings/Conclusions: as a result of its nutritional and medicinal benefits, the cuajilote fruit shows great potential as livestock feed. Additionally, it is available all year round, particularly during the dry season, when production expenses increase as a result of the lack of other food sources.
\end{abstract}

Keywords: Cuajilote, fruit, feeding, sheep, in vitro.

Citation: Pérez-Morales, S., CrosbyGalván, M.M., Ramírez-Mella, M, Bárcena-Gama, J.R., HernándezMendo, O., \& Crosby-Galván E.M. (2021). Cuajilote (Parmentiera aculeata (Kunth) Seem.): A Potential Fruit for Ruminant Feed. Agro Productividad. https://doi.org/ 10.32854/agrop. v14i10.1985

Editor in Chief: Dr. Jorge Cadena Iñiguez

Received: February 14, 2021. Accepted: October 19, 2021.

Published on-line: November 8, 2021

This work is licensed under a Creative Commons Attribution-NonCommercial 4.0 International license.

\section{INTRODUCTION}

Given its natural and cultural diversity, Mexico is one of the world's most fertile fields for ethnobotany researches. There are about 30,000 species of vascular plants, which make this country one of the richest floristic regions of the planet (Rzedowski, 1978). Though the greatest potential is found in species of the Fabaceae family, other species can also be used, particularly if they are native species (López and Del Ángel, 2010). Many trees have leaves that are used as animal feed. Some of them also have fruits, such as the pods that can be used as animal feed. These trees are usually used to provide shade and as live fences, wood, or firewood. However, they can also be used as forage, because both their foliage and their fruits have desirable nutritional qualities (Patiño, 2014). Trees such as cuajilote (Parmentiera aculeata) (Bignoniaceae) (CONABIO, 2009) produce fruits that contain water, energy, and minerals. These fruits fall during the dry 
season, during which food sources are required in the humid tropics. Usually, they are consumed by free grazing livestock (Jiménez, 1989). Therefore, the characterization and the use of the fruit of the cuajilote tree in the development of ruminant feed could help to decrease the competition for some food sources between domestic animals and people.

\section{Distribution}

Cuajilote is native to the tropical deciduous forest that covers wide expanses of land in southern and central Mexico. This tree can grow up to be $12 \mathrm{~m}$ tall, it has a wide trunk and furrowed bark. Most of its leaves are trifoliated; a few of them are simple, elliptical, glossy, and have an intense green color. The lumps of its branches have thick, small, curved, and sharp thorns, which can be found underlying each leaf. The flowers of this species grow on the stem (cauliflory) and from the twigs. Its fruit is shaped like a cylinder, it is usually curved and has thick, fleshy, and fibrous ridges. It grows up to $17 \mathrm{~cm}$ long and over $3 \mathrm{~cm}$ wide (Patiño, 2014).

\section{Habitat and Location}

The cuajilote tree is a very abundant species (Figure 1). It provides shade in open grasslands and adapts to several types of soil; however, it thrives on shaded places, in the vicinity of streams, and in warm climates (semi-warm and temperate) (Villar, 2011).

This tree is native to Mexico and northern Central America. It can be found from southern Tamaulipas and San Luis Potosí to the Yucatan Peninsula (in the coast of the Gulf Mexico) and from the center of Sinaloa to Chiapas (in the coast of the Pacific Ocean). It is a part of the deciduous tropical forest and it can adapt to the warm and humid regions of Central America. It is grown at an altitude of 2000-2240 msal and in places where the annual rain fall is higher than $1500 \mathrm{~mm}$. It has a potential yield of 1000-2000 fruits per year (Villar, 2011).

\section{Morphological Traits}

The tree can grow from 3 to $15 \mathrm{~m}$ high and up to $30 \mathrm{~cm}$ wide. Its base has a channellike structure and an abundance of short thorns, its shapeless crown branches out from the

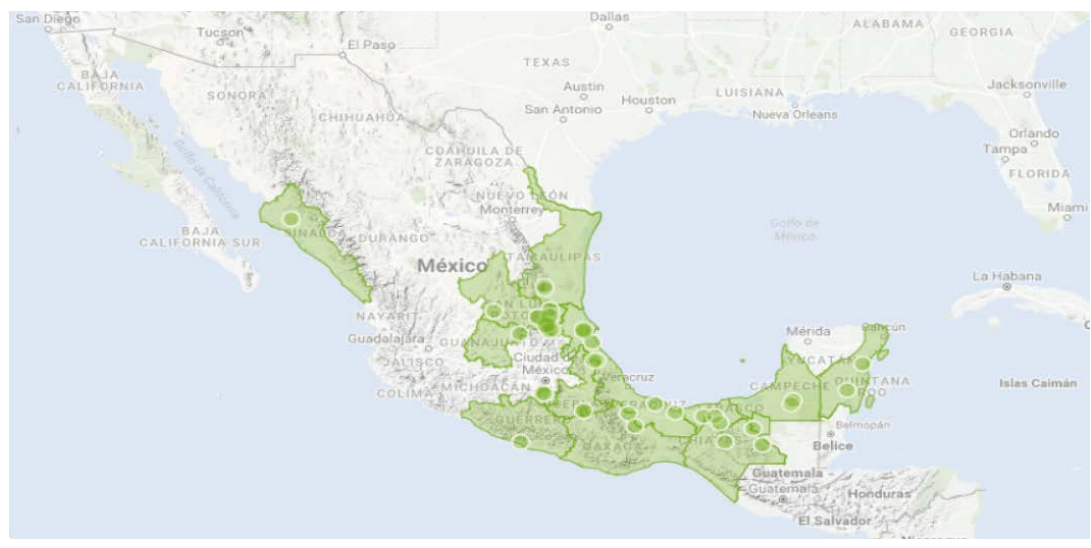

Figure 1. Main states in which the cuajilote tree can be found (Parmentiera aculeata) (INEGI 2018). 
base, its branches grow upwards, the main trunk is $30 \mathrm{~cm}$ wide, it has a yellowish greybrown furrowed bark with slight cracks, the bark is 6-15 mm thick (Sorela, 2006).

This species blooms all year long in Mexico, Puerto Rico, and Honduras. In that Central American country, the plants begin production 2-3 years after they are transplanted to their definitive location. Cuajilote develops from a flower to a ripe fruit in approximately 40 days (Villar, 2011). It blooms and bears fruit from March to December (Escamilla and Moreno, 2015).

It has several common names, including: chote, cuachilote, guajilote, cuajilote, guetoxiga, pepino de árbol (tree cucumber), guachilote, and chayote. It can be eaten raw or in various dishes; it is said to cure illnesses and diseases. Unripe berries are green yellow; ripe berries are reddish brown. It has a whitish flesh (endocarp) and numerous black seeds. It tastes like sugar cane (Villar, 2011). The inhabitants of Mexico's Mixteca region eat the fruit raw or boiled, some eat the whole fruit, while others throw out the fibrous interior (PérezGutiérrez et al., 1998; Andrade et al., 2006).

It has hermaphrodite flowers which appear alone or in groups, they grow directly from the trunk or from the twigs, they are $5-8 \mathrm{~cm}$ long and have a greenish yellow color with purple striations, they are unevenly divided to one side. The cuajilote flower has a 2-3 cm long green chalice. It has a 4.5-6.5 cm long greenish cream-colored corolla with a wide tubular shape with five giant lobes; four stamens grow from the corolla's base. It has greenish yellow filaments, grey-brown anthers, and a superior bilocular ovary (Sorela, 2006).

The cuajilote trees have $6-15 \mathrm{~cm}$ long compound leaves that are made of 2-3 secondary leaves or leaflets. They vary from $3.5 \times 1.5 \mathrm{~cm}$ to $8 \times 3 \mathrm{~cm}$. Their terminal or "point" leaflet is usually the biggest leaflet; the whole margin of the leaflets has a green upper side and a pale green underside. These trees lose their leaves once per year (Villar, 2011).

The rope-shaped, pointy, and compressed seeds are dispersed by animals (zoochory). They are 3-3.3 $\mathrm{mm}$ long and 2.5-2.8 $\mathrm{mm}$ wide. They have a dark, slightly rough, opaque, coriaceous, 0.1-0.3 mm thick seed coat. They have a straight, cordiform, compressed, slightly yellowish cream-colored embryo which takes up the whole cavity of the seeds. They have two flat, fleshy, cordiform cotyledons with two thin, literally round lobes on their upper section. They have a short, erect, lower radicle which faces the filament. They lack an endosperm (Gutiérrez et al., 2003).

\section{Uses in Ruminant Feeding}

\section{In vitro Experiments}

Various authors, including Ley de Coss et al. (2013), have evaluated P. edulis (a synonym of $P$. aculeata) in an in vitro cultivation medium in order to keep the rumen's ciliate protozoa alive. They have reported that the fruit retains a similar protozoan concentration to the one found in the rumen; this characteristic enables the evaluation of defaunation works. Likewise, they evaluated an in vitro culture medium for the rumen's ciliate protozoa in 2015 and reported that it kept a $10^{4}$ population for three days without altering the fermentation pattern. 


\section{In situ Experiments}

García-Castillo et al. (2008) carried out a research to determine the in situ degradation of the dry matter of the P. edulis fruit at various ripeness states and determined that the ripe fruit's dry matter (MS) showed greater ruminal degradation than the chilillo or unripe state (unripe fruit); however, the fruit's dry matter shows low ruminal availability and therefore they concluded that it is not a forage material that can substitute tropical forages. Based on their evaluation of the chemical composition and in situ ruminal degradation of the sprouts, leaves, and green stalks of the cuajilote tree in Chiapas, Mexico, Pinto-Ruiz et al. (2010) point out that it has approximately 15\% crude protein, moderate fiber fractions levels, low content of total condensed tannins, and acceptable degradation values (76\%).

\section{In vivo Experiments}

Moctezuma et al. (1993) carried out an in vivo digestibility test with wholemeal diets for sheep that included various levels of the cuajilote (P. edulis) fruit; they found that it improves digestibility up to a maximum level of $30 \%$ and concluded that it is a feed alternative. Additionally, they recommend including it in sheep portions, subject to availability and cost.

\section{GONGLUSIONS}

P. aculeata is an introduced species whose fruit has great potential as forage. Further animal nutrition research must be carried out to put to good use the full potential of its alleged nutritional characteristics. It is an alternative livestock feed in places with a harsher dry season.

\section{ACKNOWLEDGMENTS}

The authors would like to thank the Livestock Technological Innovation and Food Quality Section of the Guidelines for the Generation and/or Application of Knowledge (LGCAC) of the Colegio de Postgraduados (CP).

\section{REFERENGES}

Andrade-Cetto, A., Becerra-Jiménez, J., Martínez-Zurita, E., Ortega-Larrocea P., Heinrich, M. (2006). Disease-Consensus Index as a tool of selecting potential hypoglycemic plants in Chikindzonot, Yucatán, México. J Ethnopharmacol, 107(2):199-204. Doi: 10.1016/j.jep.2006.03.005

Conabio. (2009). Catálogo taxonómico de especies de México. 1. In Capital Nat. Mexico. CONABIO. Mexico City. pp. 1-222.

Escamilla, P. B. E., Moreno, C. P. (2015). Plantas medicinales de la Matamba y el Piñonal, municipio de Jamapa, Veracruz. Instituto de ecología (INECOL). Xalapa, Ver. Mex. pp 34-35.

García-Castillo, G.G., Martínez-Tinajero, J.J., Montañez-Valdez, O.D., Sánchez-Orozco, L., Posada-Cruz, S., Izaguirre-Flores, F., Martínez-Priego,G. (2008). Degradación ruminal de la materia seca del fruto cuajilote (Parmentiera edulis). Zootecnia Trop. 26(1):1-8.

Gutiérrez R.M., Pérez-González G., Zavala-Sánchez M.A., Pérez-Gutérrez, S. (2003). Actividad hipoglumicemiante de Bouvardia terniflora, Brickellia veronicaefolia y Parmentiera edulis. J. Salud Pública de México, 40: 354-358.

INEGI. Instituto nacional de estadística y geografía. (2018). XII Censo General de Población y Vivienda. Disponible en:http://www.beta.inegi.org.mx/app/buscador/default.html?q=cuajilote.Parmen

Jiménez, M.A. (1989). La producción de forrajes en México. Auch-Fira/Banco de México. 354-358 pp. 
Ley de Coss, A., De León-de León, W., Marroquín-Agreda, F. J., Lerma-Molina, J.N., Posada-Cruz, S., Cobos-Peralta, M. A. (2013). Nivel de cuajilote (Parmentiera edulis) en un medio de cultivo para protozoarios ciliados del rumen. Memoria III Congreso Internacional de Microbiología Pecuaria, IV Congreso Nacional y XIV Congreso Estudiantil de Microbiología Pecuaria. 2-7 pp.

López-Ortiz, S., Del Ángel, G.I. (2010). Folleto Técnico No. 4 Serie Sistemas Silvopastoriles. Colegio de Postgraduados Campus Veracruz. 1-2 pp.

Moctezuma, S.A., Lerma, D. E. C., Martínez, D.R., Salinas, Ch. J., Yado, P.R. (1993). Digestibilidad in vivo de dietas integrales con distintos niveles de inclusión de fruto de cuajilote (Parmentiera edulis) para ovinos. Reunión Nacional de investigación pecuaria. Jalisco, México. 27-30 pp.

Pérez-Gutiérrez RM, Pérez-González C, Zavala-Sánchez MA, Pérez-Gutiérrez S. (1998). Hypoglycemic activity of Bouvardia terniflora, Brickellia veronicaefolia, and Parmentiera edulis. Salud Pública Mex. 40 (4): $1-5$.

Pinto-Ruíz, R., Hernández, D., Gómez, H., Cobos, M.A., Quiroga, R., Pezo, D. (2010). Árboles forrajeros de tres regiones ganaderas de Chiapas, México: Usos y características nutricionales. Universidad y Ciencia Trópico Húmedo. 26(1):19-31.

RzedowskiJ. 1978. Vegetación de México. Ed. Limusa. México, D.F. 432 pp.

Sorela, B. (2006). Cuajilote (Parmentiera edulis). Tlahuimedic. 2006. Disponible en: http://www.tlahui.com/ medic/medic21/cuajilote.htm (Consulta 17/04/2017).

Villar Herrera S.L. 2011. Evaluación nutrimental del fruto Parmentiera edulis para su posible utilización en la industria alimentaria. Tesis de licenciatura. Universidad Autónoma Agraria Antonio Narro. División de Ciencia Animal Departamento de Ciencia y Tecnología de Alimentos. 16-24 pp. 